Brazilian Journal
of Chemical
Engineering

\title{
TEMPERATURE AND REACTION TIME EFFECTS ON THE STRUCTURAL PROPERTIES OF TITANIUM DIOXIDE NANOPOWDERS OBTAINED VIA THE HYDROTHERMAL METHOD
}

\author{
G. C. Collazzo $^{1 *}$, S. L. Jahn ${ }^{1}$, N. L. V. Carreño ${ }^{2}$ and E. L. Foletto ${ }^{1}$ \\ ${ }^{1}$ Department of Chemical Engineering, Federal University of Santa Maria, \\ CEP: 97105-900, Santa Maria - RS, Brazil. \\ E-mail: gabicollazzo@yahoo.com.br \\ ${ }^{2}$ Institute of Chemistry and Geoscience, Federal University of Pelotas, \\ CEP: 96010-900, Pelotas - RS, Brazil.
}

(Submitted: May 15, 2010 ; Revised: February 21, 2011 ; Accepted: March 9, 2011)

\begin{abstract}
An investigation was carried out on the synthesis of titanium dioxide nanopowders via the hydrothermal method, examining the influence of temperature $\left(150^{\circ} \mathrm{C}\right.$ and $\left.200^{\circ} \mathrm{C}\right)$ and reaction time $(6$ to $36 \mathrm{~h})$. The resulting powders were characterized by X-ray diffraction, infrared absorption spectrophotometry, transmission electron micrographs and surface area. The X-ray diffraction revealed that there was formation of a pure crystalline phase, consisting only of anatase for all conditions of synthesis. Both temperature and reaction time proved to have a slight influence on the crystallite size (from 9 to $17 \mathrm{~nm}$ ) and a significant influence on the surface area (from 86 to $168 \mathrm{~m}^{2} \cdot \mathrm{g}^{-1}$ ).

Keywords: Titanium dioxide; Hydrothermal synthesis; Nanocrystals.
\end{abstract}

\section{INTRODUCTION}

Crystalline titanium dioxide $\left(\mathrm{TiO}_{2}\right)$ occurs in three different structures: rutile (tetragonal), anatase (tetragonal), and brookite (orthorhombic) (Castañeda et al., 2002; Su et al., 2006a; Wang et al., 2007). The anatase and rutile forms have been extensively studied and, as semiconductors, are used for a variety of applications (Hidalgo et al., 2007). The anatase form appears to be the most active form of these two phases (Kabra et al., 2004; Linsebigler et al., 1995). Anatase is a metastable phase that can be converted to rutile when heated at high temperatures $\left(>600^{\circ} \mathrm{C}\right)$ (Castañeda et al., 2002). In addition to providing an excellent thermal stability, high photosensitivity (Ho and $\mathrm{Yu}, 2006$; Venkatachalam et al., 2007) and high photoreactivity, as a chemically inert, nontoxic and relatively low-cost material, $\mathrm{TiO}_{2}$ has been used in many industrial applications. Some applications include: white pigment, gas sensor, corrosion inhibitor and optical coating (Sankapal et al., 2005), solar cells (Regan and Grätzel, 1991), high constant dielectrics and high resistivity dielectrics (Sankapal et al., 2005). $\mathrm{TiO}_{2}$ has also been used to decompose carbon dioxide and generate hydrogen gas (Fox and Dulay, 1993), decompose pollutants (Hidalgo et al., 2007), and as a photocatalyst (Bouzaida et al., 2004; Guettai and Amar, 2005; Ho and Yu, 2006; Sahel et al., 2007; Sleiman et al., 2007).

Different methods have been employed for the synthesis of titanium dioxide, as follows: chemical precipitation (Pedraza and Vasquez, 1999; Scolan and Sanchez,1998), the sol-gel method (Gartner et al., 2004; Su et al., 2006b), hydrothermal (Wu et al., 2002) and solvothermal processes (Kim et al., 2003; Yin et al., 2003), combustion method (Nagaveni et

*To whom correspondence should be addressed 
al., 2003), a microemulsion-mediated process (Hong et al., 2003), electrochemical synthesis (Karuppuchamy et al., 2006), fungus-mediated synthesis (Jha et al., 2009) and chemical vapour deposition (CVD) (Jones and Chalker 2003). Venkatachalam et al. (2007) reported the preparation of titanium dioxide nanoparticles via the sol-gel method with different reaction parameters, such as different hydrolyzing agents, molar ratio, aging time and calcination temperature. They obtained nanocrystals of titanium dioxide with high surface area and different ratios of anatase /rutile.

Wang et al. (2007) reported the synthesis of anatase $\mathrm{TiO}_{2}$ nanocrystals obtained by the sol-gel method using titanium tetraisopropoxide in ethylene glycol. Titanium dioxide nanoparticles were prepared by amine-assisted sol-gel precipitation of an aqueous $\mathrm{Ti}^{4+}$ solution and further hydrothermal treatment (Hidalgo et al., 2007). The method led to high surface area values and well crystallized anatase with small crystallite size. Kim et al. (2003) investigated a solvothermal synthetic method to obtain $\mathrm{TiO}_{2}$ nanoparticles in toluene solutions with titanium isopropoxide (TIP) as precursor. The product exhibited a uniform anatase structure with mid-sized particles on the nano-scale level.

Hydrothermal synthesis has become one of the most promising and important methods employed in nanomaterial production and nanotechnology (Pavasupree et al., 2008). The process includes a simple route and produces high crystallinity oxides under moderate conditions, i.e., low temperatures and short reaction times. Due to its characteristics, this is one the most used methods to produce ceramic materials, allowing the control of the particle size, morphology and phase composition (Su et al., 2006; Wang, 2007).

The aim of this study was to investigate the effects of both temperature and reaction time on the $\mathrm{TiO}_{2}$ physical properties synthesized by the hydrothermal process. Short (6 and $12 \mathrm{~h}$ ) and long $(24$ and $36 \mathrm{~h}$ ) reaction times were investigated at low synthesis temperatures $\left(150\right.$ and $\left.200^{\circ} \mathrm{C}\right)$.

\section{MATERIALS AND METHODS}

The reagents used for the synthesis of titanium dioxide nanopowders were titanium (IV) isopropoxide $\left(\mathrm{C}_{12} \mathrm{H}_{28} \mathrm{O}_{4} \mathrm{Ti}\right)$ (Aldrich, 97\% purity) and glacial acetic acid $\left(\mathrm{CH}_{3} \mathrm{COOH}\right)$ (Aldrich, $99.7 \%$ purity). Through hydrothermal treatment, the synthesis of titanium dioxide was performed at different reaction times $(6,12,24$ and $36 \mathrm{~h})$ and at different temperatures $\left(150\right.$ and $\left.200^{\circ} \mathrm{C}\right)$. The molar composition of the reaction mixture was $1 \mathrm{TiO}_{2}: 10 \mathrm{CH}_{3} \mathrm{COOH}: 150 \mathrm{H}_{2} \mathrm{O}$. Glacial acetic acid (36 mL) was slowly added to $20 \mathrm{~mL}$ of titanium (IV) isopropoxide in a water bath at $0^{\circ} \mathrm{C}$, under constant stirring. Afterwards, $170 \mathrm{~mL}$ of deionized water were gently added to the mixture, also under constant stirring. After vigorous agitation for one hour, the solution underwent ultrasonic treatment for $30 \mathrm{~min}$. Once again, vigorous agitation was applied for $5 \mathrm{~h}$. Afterwards, the solution was poured into Teflon jars and placed in stainless steel autoclaves (Bayati et al., 2008). The autoclaves were placed in an oven previously heated to $70^{\circ} \mathrm{C}$ in order to carry out the ageing process for $12 \mathrm{~h}$. Following the ageing process, the hydrothermal treatment was carried out at $150^{\circ} \mathrm{C}$ and $200^{\circ} \mathrm{C}$ for $6,12,24$ and $36 \mathrm{~h}$. Subsequently, the autoclaves were removed from the oven and cooled in running water. Eventually, the precipitate was washed with distilled water, centrifuged and dried in an oven at $100^{\circ} \mathrm{C}$ for $12 \mathrm{~h}$. The solid sample obtained was finely ground using a mortar and pestle and stored in plastic containers.

The resultant powder was characterized by X-ray diffraction, infrared spectroscopy and surface area measurements. X-ray diffraction (XRD) patterns were obtained using a Bruker D8 Advance diffractometer. The X-ray source was $\mathrm{Cu}-\mathrm{K} \alpha$ radiation, powered at $40 \mathrm{kV}$ and $40 \mathrm{~mA}$. Data were collected from 20 to $80^{\circ}(2 \theta)$ with a step size of $0.05^{\circ}$ and a count time of $35 \mathrm{~s}$. The average nanocrystal size was determined using the Sherrer equation (Ikezawa et al., 2001): $\mathrm{D}=\mathrm{K} \cdot \lambda /(\beta \cdot \cos \theta)$, where $\mathrm{D}$ is the average crystallite size, $\mathrm{K}$ is the Sherrer constant $(0.90), \lambda$ is the wavelength of the $\mathrm{X}$-ray radiation $(0.15425 \mathrm{~nm}$ for $\mathrm{Cu}-\mathrm{K} \alpha), \beta$ is the peak width at half height and $\theta$ corresponds to the peak position (in the current study, $2 \theta=25.35$ ).

By means of infrared spectroscopy, infrared spectra of all samples pressed into $\mathrm{KBr}$ pellets were recorded by a Bruker tensor 27 FTIR spectrometer. IR spectra were measured in the range $4000-400 \mathrm{~cm}^{-1}$.

The transmission electron micrographs (TEM) were obtained using a model JEM-2100 microscope. Test samples were prepared by ultrasonic dispersion of the powder in alcohol. A drop of the resulting suspension was spread onto a carbon-coated grid and allowed to dry at room temperature before testing.

The BET surface areas were obtained from nitrogen adsorption isotherms at $77 \mathrm{~K}$, conducted on a Quantachrome Autosorb Automated Gas Sorption system, at a relative pressure $(\mathrm{P} / \mathrm{Po})$ from 0 to 0.99 . 


\section{RESULTS AND DISCUSSION}

Figures 1(a) and 1(b) show a series of XRD patterns of the prepared $\mathrm{TiO}_{2}$ samples following the hydrothermal treatment at $150^{\circ} \mathrm{C}$ and $200^{\circ} \mathrm{C}$ at various time periods. All diffraction peaks show the complete formation of the crystalline anatase phase and were indexed according to the JCPDS card No. 89-4921. The nanocrystalline anatase structure was confirmed by (101), (004), (200), (105), (211), (204) and (116) diffraction peaks. No peaks related to either the rutile or brookite phases were observed in the XDR patterns. The hydrothermal synthesis route presents the advantage of obtaining phase-pure $\mathrm{TiO}_{2}$ nanoparticles at both lower temperatures and reaction times. From the diffractogram, the widths of the bases of the peaks and their intensity characterize the size of the nanocrystals, because small crystals may promote a more intense spreading due to internal reflections that occur in the system. Considering the diffractograms shown in Fig. 1 (a) and (b), it can be observed that the samples obtained at $150^{\circ} \mathrm{C}$ present slightly broader peaks, which are also reduced in intensity compared to samples synthesized at $200^{\circ} \mathrm{C}$, revealing that the nanocrystals obtained at lower temperatures have a smaller size. This fact is evidenced by the calculation of the average crystallite size using the Scherrer equation, as shown in Table 1. Comparing the samples synthesized at both temperatures, larger crystallite sizes were observed in all samples treated at $200^{\circ} \mathrm{C}$ at all reaction times. The crystallite sizes increase considerably as the temperature increases due to the nanocrystal coalescence that takes place. In addition, in Table 1 , it is observed that the average crystallite size increases with reaction time. An increased contact time favours greater coalescence, allowing time to control the nanocrystal growth. Comparing all samples synthesized under all synthesis conditions, the sample synthesized at the shortest time and lowest temperature $\left(6 \mathrm{~h}\right.$ and $\left.150^{\circ} \mathrm{C}\right)$ presented the smallest crystallite size of $8.9 \mathrm{~nm}$, while the one synthesized under the highest synthesis conditions $\left(36 \mathrm{~h}\right.$ and $\left.200^{\circ} \mathrm{C}\right)$ presented the biggest crystallite size of $17.2 \mathrm{~nm}$.

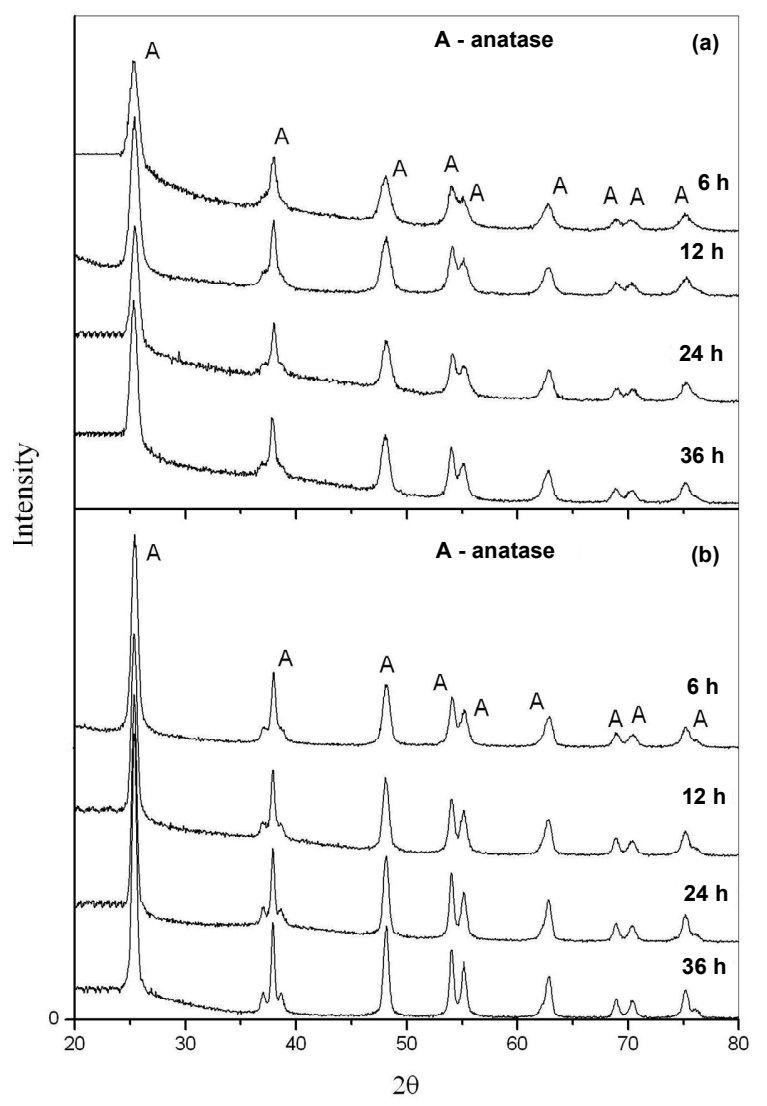

Figure 1: XRD of the samples synthesized at temperatures of (a) $150^{\circ} \mathrm{C}$ and (b) $200^{\circ} \mathrm{C}$ for different reaction times.

Table 1: BET surface area, average pore size, average crystalline size and total pore volume of $\mathrm{TiO}_{2}$ obtained by the hydrothermal method under different conditions.

\begin{tabular}{|c|c|c|c|c|c|}
\hline $\begin{array}{c}\text { Temperature } \\
\left({ }^{\circ} \mathrm{C}\right)\end{array}$ & $\begin{array}{l}\text { Reaction Time } \\
\text { (h) }\end{array}$ & $\begin{array}{c}\text { Average crystallite } \\
\text { size (nm) }\end{array}$ & $\underset{\left(\mathrm{m}^{2} \cdot \mathrm{g}^{-1}\right)}{\mathrm{S}_{\mathrm{BET}}}$ & $\begin{array}{l}\text { Pore size } \\
\text { (nm) }\end{array}$ & $\begin{array}{c}\text { Pore volume } \\
\left(\mathrm{cm}^{3} \cdot \mathrm{g}^{-1}\right)\end{array}$ \\
\hline \multirow{4}{*}{150} & 6 & 8.9 & 169 & 6.3 & 0.33 \\
\hline & 12 & 9.4 & 165 & 6.5 & 0.31 \\
\hline & 24 & 10.1 & 161 & 7.8 & 0.30 \\
\hline & 36 & 11.4 & 158 & 8.3 & 0.29 \\
\hline \multirow{4}{*}{200} & 6 & 12.0 & 129 & 9.6 & 0.32 \\
\hline & 12 & 13.7 & 113 & 11.3 & 0.31 \\
\hline & 24 & 16.1 & 99 & 12.8 & 0.30 \\
\hline & 36 & 17.2 & 86 & 13.6 & 0.26 \\
\hline
\end{tabular}


Fig. 2 shows the isothermal adsorption/desorption of nitrogen related to the titanium dioxide samples synthesized at temperatures of $150^{\circ} \mathrm{C}$ and $200^{\circ} \mathrm{C}$ and at 6 and $36 \mathrm{~h}$ reaction time. All isothermal adsorption and desorption curves show a type IV isotherm and hysteresis loops typical of mesoporous materials (Rouquerol et al., 1999). The isotherms of the other samples (not shown here) showed similar behaviour. With respect to the samples obtained by the hydrothermal method, the surface area data, the average pore diameters and the total pore volume are summarized in Table 1. Analysing the results for the surface area, at a synthesis temperature of $150^{\circ} \mathrm{C}$, the surface area ranged from $169(6 \mathrm{~h})$ to $158 \mathrm{~m}^{2} \cdot \mathrm{g}^{-1}(36 \mathrm{~h})$, which corresponds to a difference of only $6 \%$. However, nanocrystals synthesized at $200^{\circ} \mathrm{C}$ had a surface area that ranged from $129(6 \mathrm{~h})$ to $86 \mathrm{~m}^{2} \cdot \mathrm{g}^{-1}$ $(36 \mathrm{~h})$, which corresponds to a difference of $33 \%$. The results show that the reaction time has little

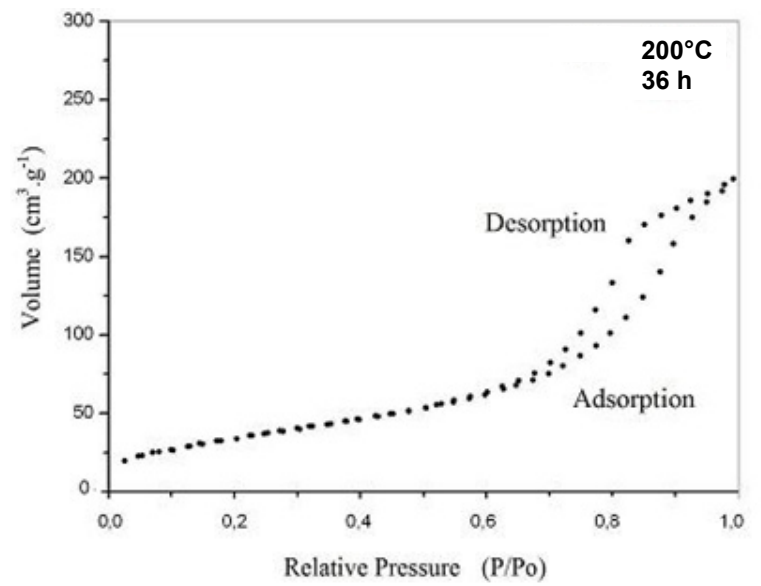

(a)

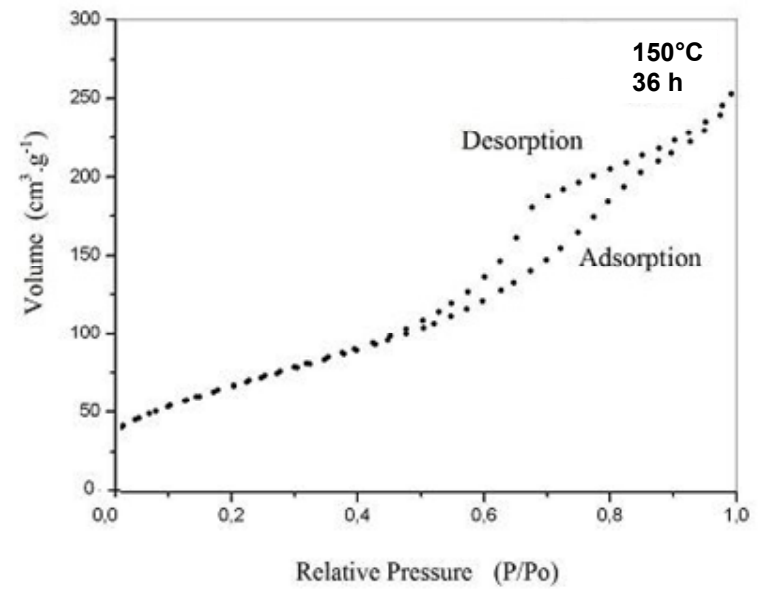

(c) influence on the surface area at lower temperatures; however, it has a significant influence at higher temperatures. Comparing the areas from the samples obtained at a reaction time of $6 \mathrm{~h}$, a variation from $169 \mathrm{~m}^{2} \cdot \mathrm{g}^{-1}\left(150^{\circ} \mathrm{C}\right)$ to $129 \mathrm{~m}^{2} \cdot \mathrm{g}^{-1}\left(200^{\circ} \mathrm{C}\right)$ is observed, which corresponds to a difference of $23 \%$. Concerning the samples synthesized at the longest reaction time, $36 \mathrm{~h}$, the surface areas range from 158 $\left(150^{\circ} \mathrm{C}\right)$ to $86 \mathrm{~m}^{2} \cdot \mathrm{g}^{-1}\left(200^{\circ} \mathrm{C}\right)$, which corresponds to a difference of $45 \%$. Thus, temperature has been shown to influence significantly the surface area over long treatment periods. The highest surface area values were observed for mild treatment conditions (temperature and time) because, under those conditions, smaller crystallite sizes are found. In general, hydrothermal treatment leads to high surface area values, as has been widely reported in the literature for hydrothermal synthesis (Kolen'ko et al., 2004; Kominami, et al., 1997).

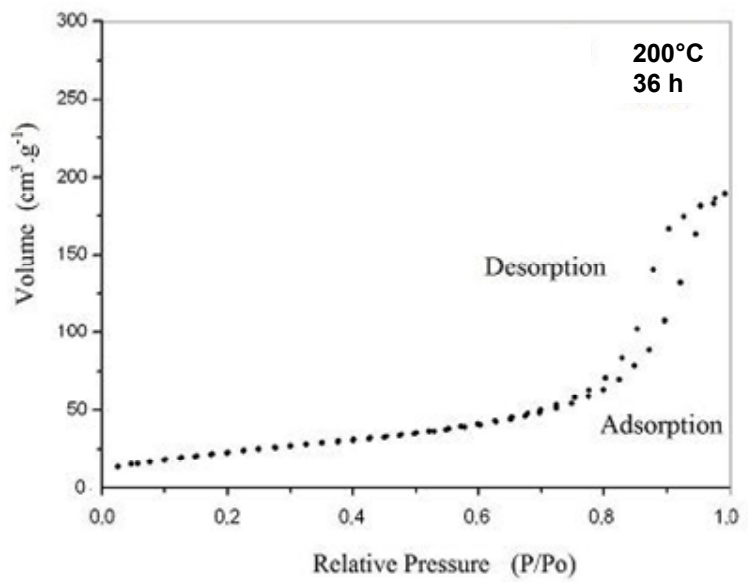

(b)

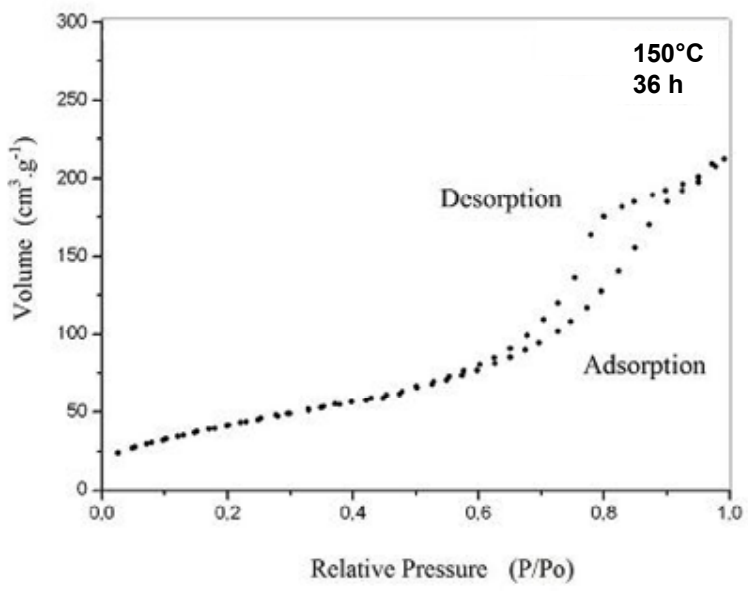

(d)

Figure 2: $\mathrm{N}_{2}$ adsorption-desorption isotherms for sample synthesized at (a) and (b) $200^{\circ} \mathrm{C}$; (c) and (d) $150^{\circ} \mathrm{C}$, for reaction times of 6 and $36 \mathrm{~h}$. 
The samples synthesized at $150^{\circ} \mathrm{C}$ presented an average pore size ranging from $6.3 \mathrm{~nm}(6 \mathrm{~h})$ to 8.3 $\mathrm{nm}(36 \mathrm{~h})$, and the samples synthesized at $200^{\circ} \mathrm{C}$ presented an average pore size ranging from $9.6 \mathrm{~nm}$ (6h) to $13.6 \mathrm{~nm}$ (36h). In this study, the values found for pore diameter ranged from 2 to $50 \mathrm{~nm}$; hence, the material is regarded as being mesoporous (Gregg and Sing, 1982). Pore diameter increases with time and temperature conditions due to the increase in the crystal size of $\mathrm{TiO}_{2}$. The characterization of mesoporosity is probably due to a variety of accumulated pore voids between the particles. Mesoporous $\mathrm{TiO}_{2}$ materials have been receiving considerable attention due to their remarkable mesostructure and their synthesis has been extensively studied under different conditions. Huang et al. (2005) prepared mesoporous $\mathrm{TiO}_{2}$ materials by the sol-gel process at room temperature using tetrabutyl titanate as the precursor in the absence of any templates. Antonelli and Ying (1995) synthesized mesoporous $\mathrm{TiO}_{2}$ materials by a modified sol-gel method using phosphorus surfactants as templates. Pavasupree et al. (2008) synthesized mesoporous anatase $\mathrm{TiO}_{2}$ nanopowder by the hydrothermal method at $130^{\circ} \mathrm{C}$ for $12 \mathrm{~h}$. All researchers mentioned in the current study observed that type IV isotherms exhibit hysteresis loops that are typical of mesoporous material. For all samples, pore volumes were approximately $0.30 \mathrm{~cm}^{3} \cdot \mathrm{g}^{-1}$.

Fig. 3 shows the micrographs of $\mathrm{TiO}_{2}$ samples treated hydrothermally at 150 and $200^{\circ} \mathrm{C}$ for 6 and $36 \mathrm{~h}$. TEM images indicate that the $\mathrm{TiO}_{2}$ nanoparticles are reasonably uniform in size for a given synthesis condition. The images demonstrate the formation of crystalline $\mathrm{TiO}_{2}$ aggregates with a size of the nanoparticles of about $10-20 \mathrm{~nm}$. The size of the nanoparticles obtained by TEM micrographs is consistent with the crystallite size estimated from $\mathrm{XRD}$ analysis.

In Fig. 4, bands in the region 400 a $800 \mathrm{~cm}^{-1}$, which are assigned to vibrations of the Ti-O bonds of the crystalline anatase phase, can be observed in both samples at all reaction times. The band near $500 \mathrm{~cm}^{-1}$ is assigned to a vibration of pure titanium dioxide for the crystalline anatase phase (Ivanova and Harizanova, 2001; Ayers and Hunt, 1998). Vibrations ranging from 770 to $800 \mathrm{~cm}^{-1}$ are typical of Ti-O bonds for $\mathrm{TiO}_{\mathrm{n}}$ compounds with $\mathrm{n}<6$ (Ivanova and Harizanova, 2001; Karuppuchamy and Jeong, 2006). In addition, changes in the intensity of the bands ranging from 400 to $800 \mathrm{~cm}^{-1}$ were observed. The increase of both reaction time and temperature resulted in more intense bands. This fact may be due to the increase of crystallite size.
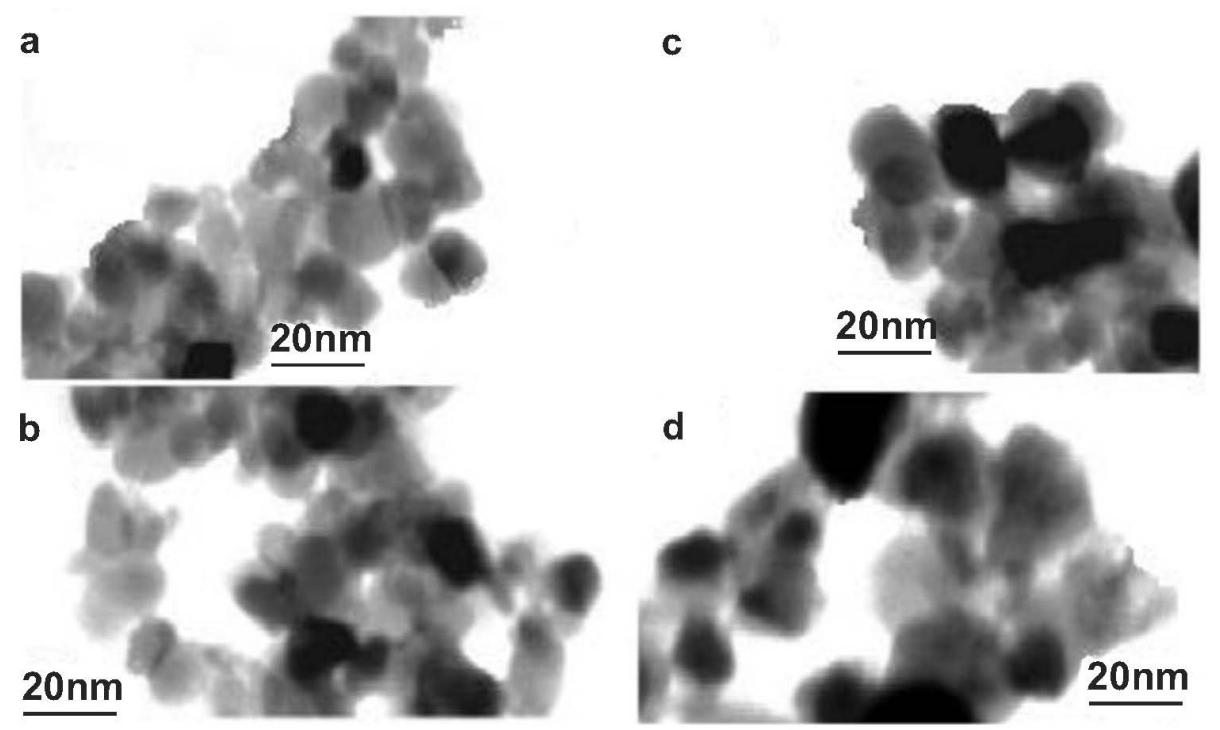

Figure 3: TEM images of the $\mathrm{TiO}_{2}$ samples synthesized at (a) and (b) $150^{\circ} \mathrm{C}$; (c) and (d) $200^{\circ} \mathrm{C}$, for different times $(6$ and $36 \mathrm{~h})$. 


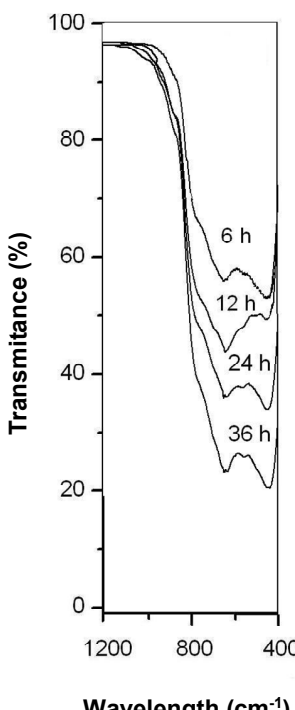

(a)

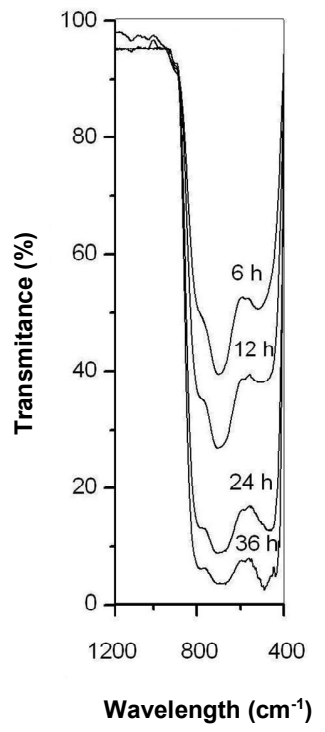

(b)

Figure 4: FTIR spectra of the $\mathrm{TiO}_{2}$ from syntheses performed at the temperatures (a) $150^{\circ} \mathrm{C}$ and (b) $200^{\circ} \mathrm{C}$ for different reaction times.

\section{CONCLUSIONS}

This study investigated the synthesis of titanium dioxide anatase phase, with high surface area and nanosized crystallites, obtained by a hydrothermal process. It was shown that the reaction time exerts little influence on the surface area at lower temperatures, but has a significant influence at higher temperatures. Temperature was shown to exert a significant influence on the surface area under elevated thermal conditions. A small range of crystallite size values may result in a significant variation of surface area. Both temperature and reaction time were shown to have little influence on the crystallite size. A major advantage of this route is that the synthesis of titanium dioxide anatase phase can be performed under moderate temperatures and reaction times.

\section{ACKNOWLEDGEMENTS}

The authors would like to thank the Brazilian agency CAPES for financial support.

\section{REFERENCES}

Antonelli, D. M. and Ying, Y. J., Synthesis of hexagonally packed mesoporous $\mathrm{TiO}_{2}$ by a modified sol-gel method. Angew. Chem. Int. Ed., 34, 2014-2017 (1995).
Ayers, M. R. and Hunt, A. J., Titanium oxide aerogels prepared from titanium metal and hydrogen peroxide. J. Mater. Lett., 34, 292-293 (1998).

Bayati, B., Babaluo, A. A. and Karimi, R., Hydrothermal synthesis of nanostructure $\mathrm{NaA}$ zeolite: The effect of synthesis parameters on zeolite seed size and crystallinity. J. Eur. Ceram. Soc., 28, 2653-2657 (2008).

Bouzaida, I., Ferronato, C., Chovelon, J. M., Rammah, M. E. and Herrmann, J. M., Heterogeneous photocatalytic degradation of the anthraquinonic dye, Acid Blue 25 (AB25): a kinetic approach. J. Photochem. Photobiol. A: Chem., 168, 23-30 (2004).

Castañeda, L., Alons, L. C., Ortiz, A., Andrade, E., Saniger, J.M. and Rañuelos, J.G., Spray pyrolysis deposition and characterization of titanium oxide thin films. Mater. Chem. Phys., 77, 938-944 (2002).

Fox, M. A. and Dulay, M. T., Heterogeneous photocatalysis. Chem. Rev., 93, 341-357, (1993).

Gartner, M., Scurtu, R., Ghita, A., Zaharescu, M., Modreanu, M., Kokkorisc, M., Kordas, G. and Trapalis, C., Spectroellipsometric characterization of sol-gel $\mathrm{TiO}_{2}-\mathrm{CuO}$ thin coatings. Thin Solid Films, 455, 417-421 (2004).

Gregg S. J. and Sing, K. S. W., Adsorption surface area and porosity. 2 Ed., Academic Press, London, (1982). 
Guettai, N. and Amar, A. H., Photocatalytic oxidation of methyl orange in presence of titanium dioxide in aqueous suspension. Part II: Kinetics study, Desalination, 185, 439-448 (2005).

Hidalgo, M. C., Aguilar, M., Maicu, M., Navio, J. A. and Colón, G., Hydrothermal preparation of highly photoactive $\mathrm{TiO}_{2}$ nanoparticles. Catal. Today, 129, 51-52 (2007).

Ho, W. and $\mathrm{Yu}$, J. C., Sonochemical synthesis and visible light photocatalytic behavior of $\mathrm{Cd} / \mathrm{TiO}_{2}$ nanoparticles. J. Mol. Catal. A: Chem., 247, 268274 (2006).

Hong, S. S., Lee, M. S., Lee, G. D., Lim, K. T. and Ha, B. J., Synthesis of titanium dioxides in waterin-carbon dioxide microemulsion and their photocatalytic activity. Mater. Lett., 57, 29752979 (2003).

Huang, D., Luo, G., Yang, L. and Wang, Y., Synthesis of mesoporous $\mathrm{TiO}_{2}$ materials with high specific area using inorganic acids as catalysts. China Particuology, 3, 176-180 (2005).

Ikezawa, S., Homyara, H., Kubota, T., Suzuki, R., Koh, S., Mutuga, F., Yoshioka, T., Nishiwaki, A., Ninomiya, Y., Takahashi, M., Baba, K., Kida, K., Hara, T. and Famakinwa, T., Applications of $\mathrm{TiO}_{2}$ film for environmental purification deposited by controlled electron beam-excited plasma. Thin Solids Films, 386, 173-176 (2001).

Ivanova, T. and Harizanova, A., Characterization of $\mathrm{TiO}_{2}$ and $\mathrm{TiO}_{2}-\mathrm{MnO}$ oxides prepared by Sol-Gel method, Solid State Ionics, 138, 228-230 (2001).

Jha, A. K., Prasad, K. and Kulkarni, A. R., Synthesis of $\mathrm{TiO}_{2}$ nanoparticles using microorganisms. Colloids Surf.. B: Biointerfaces, 71, 226-229 (2009).

Jones, A. C. and Chalker, P. R., Some recent developments in the chemical vapours deposition of electroceramic oxides. J. Phys., D: Appl. Phys., 36, R80 (2003).

Kabra, K., Chaudhary, R. and Sawhney, R. L., Treatment of hazardous organic and inorganic compounds through aqueous-phase photocatalysis: a review. Ind. Eng. Chem. Res., 43, 7683-7696 (2004).

Karuppuchamy, S. and Jeong, J. M., Synthesis of nano-particles of $\mathrm{TiO}_{2}$ by simple aqueous route. $\mathrm{J}$. Oleo Sci., 55, 264-266 (2006).

Karuppuchamy, S., Iwasaki, M. and Minoura, H., Electrochemical properties of electrosynthesized $\mathrm{TiO}_{2}$ thin films. Appl. Surf. Sci., 253, 2924-2929 (2006).

Kim, C. S., Moon, B. K., Park, J. H. and Son, S. M., Synthesis of nanocrystalline $\mathrm{TiO}_{2}$ in toluene by a solvothermal route. J. Cryst. Growth, 254, 405410 (2003).

Kolen'ko, Y. V., Churagulov, B. R., Kunst, M., Mazerolles, L. and Colbeau-Justin, C., Photocatalysis properties of titania powders prepared by hydrothermal method. Appl. Catal. B: Environ., 54, 51-58 (2004).

Kominami, H., Kato, J., Takada, Y., Doushi, Y., Ohtani, B., Nishimoto, S., Inoue, M., Inui, T. and Kera, Y., Novel synthesis of microcrystalline titanium (IV) oxide having high thermal stability and ultra-high photocatalytic activity: thermal decomposition of titanium(IV) alkoxide in organic solvents. Catal. Lett., 46, 235-240 (1997).

Li, H., Xie, T., Wang, H. and Du, Z., A facile solution-phase synthesis of high quality watersoluble anatase $\mathrm{TiO}_{2}$ nanocrystals. J. Colloid Interface Sci., 314, 337-340 (2007).

Linsebigler, A. L., Lu, G. and Yates Jr, J. T., Photocatalysis on $\mathrm{TiO}_{2}$ surfaces: principles, mechanisms, and selected results. Chem. Rev., 95, 735-758 (1995).

Nagaveni, K., Sivalingam,G., Hegde, M. S. and Madras, G., Solar photocatalytic degradation of dyes: high activity of combustion synthesized nano $\mathrm{TiO}_{2}$. Appl. Catal. B: Environ., 48, 83-93 (2003).

Pavasupree, S., Jitputti, J., Ngamsinlapasathian, S. and Yoshikawa, S., Hydrothermal synthesis, characterization, photocatalytic activity and dyesensitized solar cell performance of mesoporous anatase $\mathrm{TiO}_{2}$ nanopowders, Mater. Res. Bull., 43, 149-157 (2008).

Pedraza, F. and Vasquez, A., Obtention of $\mathrm{TiO}_{2}$ rutile at room temperature through direct oxidation of $\mathrm{TiCl}_{3}$. J. Phys. Chem. Solids, 60, 445-448 (1999).

Regan, B. O', and Grätzel, M., A low-cost, highefficiency solar cell based on dye-sensitized colloidal $\mathrm{TiO}_{2}$ films. Nature, 335, 737-740 (1991).

Rouquerol, F., Rouquerol, J. and Singh, K., Adsorption by powders and porous solids, Academic Press, San Diego (1999).

Sahel, K., Perol, N., Chermette, H., Bordes, C., Derriche, Z. and Guillard, C., Photocatalytic decolorization of Remazol Black 5 (RB5) and Procion Red MX-5B - Isotherm of adsorption, kinetic of decolorization and mineralization. Appl. Catal. B: Environ., 77, 100-109 (2007).

Sankapal, B. R., Lux- Steiner, M. C. and Ennaoui, A., Synthesis and characterization of anatase$\mathrm{TiO}_{2}$ thin films. Appl. Surf. Sci., 239, 165-170 (2005). 
Scolan, A. and Sanchez, C., Synthesis and characterization of surface-protected nanocrystalline titania particles, Chem. Mater., 10, 3217-3223 (1998).

Sleiman, M., Vildozo, D., Ferronato, C. and Chovelon, J. -M., Photocatalytic degradation of azo dye Metanil Yellow: Optimization and kinetic modeling using a chemometric approach. Appl. Catal. B: Environ., 77, 1-11 (2007).

Su, C., Lin, K. F and Lin, Y. H., Preparation and characterization of high-surface-area titanium dioxide by sol-gel process. J. Porous Mater., 13, 251-258, (2006a).

Su, C., Tseng, C. M., Chen, L. F., You, B. H., Hsu, B. C. and Chen, S. S., Sol-hydrothermal preparation and photocatalysis of titanium dioxide. Thin Solids Films, 498, 259-265 (2006b).
Venkatachalam, V., Wang, P., Wang, D., Palanichamy, M. and Murugesan,V., Sol-Gel preparation and characterization of nanosize $\mathrm{TiO}_{2}$ : Its photocatalytic performance. Mater. Chem. Phys., 104, 454-459 (2007).

Wang, G., Hydrothermal synthesis and photocatalytic activity of nanocrystalline $\mathrm{TiO}_{2}$ powders in ethanol-water mixed solutions. J. Mol. Catal. A: Chem., 274, 185 -191 (2007).

Wu, M., Lin, G., Chen, D., Wang, G., He, D., Feng, $\mathrm{S}$. and $\mathrm{Xu}, \mathrm{R}$., Sol-hydrothermal synthesis and hydrothermal structural evolution of nanocrystal titanium dioxide. Chem. Mater., 14, 1974 (2002).

Yin, S., Fujishiro, Y., Wu, J., Aki, M. and Sato, T., Synthesis and photocatalytic properties of fibrous titania by solvothermal reactions. J. Mater. Process. Technol., 137, 45-48 (2003). 